\title{
Phenology, Thermal Indices and Yield Prediction Models of Indigenous Aromatic Rice of West Bengal, India
}

\author{
Sibajee Banerjee $^{1^{*}}$, Mrityunjay Ghosh $^{1^{*}}$ and Debasis Mazumder ${ }^{2}$ \\ ${ }^{1}$ Department of Agronomy, ${ }^{2}$ Department of Agricultural Statistics, Bidhan Chandra Krishi \\ Viswavidyalaya, Mohanpur, Nadia, West Bengal, India \\ *Corresponding author
}

\section{A B S T R A C T}

The phenological development and thermal unit requirements of seven aromatic rice landraces of West Bengal were studied in randomized block design (RBD) with 3 replications at ' $\mathrm{C}$ ' Block Farm ( $22^{\circ}$ 99' N, $88^{\circ} 45^{\prime}$ ' E, 9.75 m.s.l.), Bidhan Chandra Krishi Viswavidyalaya, Kalyani, West Bengal, India during kharif (wet) season of 2008 and 2009. All seven indigenous scented rice cultivars were long-duration types $(140.0-148.3$

Keywords

Aromatic rice, Phenology, Regression model, Thermal indices, Yield

\section{Article Info}

Accepted:

12 February 2018 Available Online: 10 March 2018 days) and differed slightly among themselves towards attainment of different phenophases and accumulation of heat units. Mean cultivar days from sowing to emergence, $4^{\text {th }}$ leaf emergence, active tillering, panicle initiation, 50\% flowering, milk, dough and maturity stages were 3.9, 21.4, 47.1, 73.6, 111.3, 122.5, 133.6, 122.5, 133.6 and 144.6 days, respectively. Mean growing degree days (GDD), heliothermal units (HTU) and photohermal units (PTU) were $1449 \pm 83,6473 \pm 453$ and $18439 \pm 999$ during vegetative stage, $729 \pm 10,4465 \pm 223$ and $8679 \pm 167$ during reproductive stage and $530 \pm 23,4389 \pm 254$ and $6035 \pm 255$ during ripening stage, respectively. Based on accumulated GDD, HTU and PTU for entire life cycle, the cultivars could be arranged as: Radhunipagal > Chinikamini $>$ Mohanbhog > Badshabhog > Khasdhan > Gobindabhog > Kalojira. The correlation studies revealed that GDD and HTU at tiller production stage had positive influence on number of panicle $\mathrm{m}^{-2}$, while HTU at ripening stage showed positive impact on grain filling and development leading to higher grain yield. The regression model for grain yield (Y= $3.93-0.0138$ GDDM-D** -0.000724 HTUM-D*) showed associations with GDD and HTU both during milk to dough stage and accounted for $34 \%$ variation at $1 \%$ level of significance.

\section{Introduction}

There are about 25-30 aromatic rice landraces in West Bengal, which are cultivated by the farmers in different parts of the state for hundreds of years. It is estimated that about $3,00,000$ tonnes of such premium rices are produced every year (Bhattacharya, 2003), which have different end-uses like cooked table rice, dessert (payas), biriyani, etc. With the introduction of high-yielding varieties, the cultivation of such scented rice cultivars is being marginalized, but they are still grown by the farmers mainly for domestic consumption, 
social and religions functions. Weather variability is considered as one of the major factors of inter-annual variability in crop growth and yield in all environments. In the event of unpredictable weather conditions during kharif season (south-west monsoon period, June-October), agro-meteorological indices such as growing degree days (GDD), heliothermal units (HTU), etc. can be quite useful in predicting the growth and yield of these aromatic rice landraces in the region. Thus, it is necessary to generate information on phenological development and effects of weather parameters on indigenous aromatic rice as well as development of yield prediction models for necessary refinement of production technologies in future.

\section{Materials and Methods}

A field experiment was conducted to study the phenological development and thermal unit requirements of aromatic rice landraces of West Bengal at ' $C$ ' Block Farm $\left(22^{0} 5^{\prime} \mathrm{N}, 89^{0}\right.$ 0' E and 9.75 m.s.1.) of Bidhan Chandra Krishi Viswavidyalaya, Kalyani, West Bengal, India during kharif (wet) season of 2008 and 2009. Seven indigenous scented rice cultivars (viz. Gobindabhog, Badshabhog, Mohanbhog, Radhunipagal, Kalojira, Chinikamini and Khasdhan) were transplanted in $4 \mathrm{~m} \times 3 \mathrm{~m}$ plots with a spacing of $15 \mathrm{~cm} \times 15 \mathrm{~cm}$ in a randomized block design (RBD) with 3 replications. A uniform fertilizer dose consisting of FYM @ $5 \mathrm{t} \mathrm{ha}^{-1}$ as basal and mustard cake@ 0.25 and $0.25 \mathrm{t} \mathrm{ha}^{-1}$ were applied to all experimental plots at 3 and 6 weeks after transplanting.

A total of eight phenophases (viz. $\mathrm{P}_{1}=$ sowing to emergence, $\mathrm{P}_{2}=$ emergence to $4^{\text {th }}$ leaf emergence, $\mathrm{P}_{3}=4^{\text {th }}$ leaf emergence to active tillering, $\mathrm{P}_{4}=$ active tillering to panicle initiation, $\mathrm{P}_{5}=$ panicle initiation to $50 \%$ flowering, $\mathrm{P}_{6}=50 \%$ flowering to milk, $\mathrm{P}_{7}=$ milk to dough and $\mathrm{P}_{8}=$ dough to maturity) were studied by visiting the field at every 2-3 days intervals. Daily weather data was collected from Agromet Observatory of AICRP on Agrometeorology, B.C.K.V. Centre, Kalyani, Nadia and thermal indices were calculated by the following formulae.

Growing degree days $($ GDD $)=[($ Tmax. + Tmin.) / 2] - $10{ }^{0} \mathrm{C}$

Heliothermal units $(\mathrm{HTU})=$ GDD $*$ Bright sunshine hour

Photothermal units $(\mathrm{PTU})=$ GDD* Day length

The correlation studies between thermal indices and yield associated characters were made and yield prediction models were developed for scented rice in the investigation.

\section{Results and Discussion}

\section{Phenology}

Among seven aromatic rice landraces, number of days to maturity pooled over two years varied between 140.0 days (Kalojira) and 148.3 days (Radhunipagal) (Table 1). So, all the cultivars in the study were long-duration types and the differences in growth duration were mainly due to variation in length of vegetative phase from 69.5 to 78.0 days. The finding was in conformity with the opinion of Oldeman et al., (1987). Mean cultivar days from sowing to emergence, $4^{\text {th }}$ leaf emergence, active tillering, panicle initiation, 50\% flowering, milk, dough and maturity stages were 3.9, 21.4, 47.1, 73.6, 111.3, 122.5, 133.6, $122.5,133.6$ and 144.6 days, respectively.

Kalojira was the earliest cultivar (68.0 and 71.0 days) to complete the vegetative stage in both the years of experimentation; while Badshabhog and Radhunipagal required minimum days (37.0 days) for reproductive stage during 2008 and 2009, respectively and 
Gobindabhog completed the ripening stage in lowest number of days (32.0 and 30.3 days) during both the years of investigation (data not shown).

\section{Thermal indices}

Mean air temperature and bright sunshine hours at eight phenophases were: $30.8^{\circ} \mathrm{C}$ and 4.0 hours (sowing to emergence), $29.3^{\circ} \mathrm{C}$ and 3.2 hours (emergence to $4^{\text {th }}$ leaf emergence), $29.9^{\circ} \mathrm{C}$ and 4.6 hours ( $4^{\text {th }}$ leaf emergence to active tillering), $29.5^{\circ} \mathrm{C}$ and 5.0 hours (active tillering to panicle initiation), $29.4^{\circ} \mathrm{C}$ and 6.1 hours (panicle initiation to $50 \%$ flowering), $26.5^{\circ} \mathrm{C}$ and 7.7 hours (50\% flowering to milk), $25.9^{\circ} \mathrm{C}$ and 9.1 hours (milk to dough) and $25.4^{0} \mathrm{C}$ and 8.0 hours (dough to maturity).

The meteorological parameters indicated that mean air temperature was near-plateau stage both during vegetative and reproductive phases, which declined in ripening phase. On the other hand, bright sunshine hours per day were less in vegetative stage mainly due to cloudy weather during south-west monsoon season, which increased progressively during reproductive and ripening stages of rice crop.

Mean growing degree days, heliothermal units and photohermal units were $1449 \pm 83$, $6473 \pm 453$ and $18439 \pm 999$ during vegetative stage, $729 \pm 10, \quad 4465 \pm 223$ and $8679 \pm 167$ during reproductive stage and $530 \pm 23$, $4389 \pm 254$ and $6035 \pm 255$ during ripening stage, respectively (Table 2). The accumulated GDD and HTU from emergence to maturity of seven long-duration aromatic rice cultivars were 2708 and 15327, respectively in the study; which were somewhat greater than 2102 and 12031 in a medium duration variety cv. Polasa Prabha in Hyderabad, Andhra Pradesh (Sreenivas et al., 2010). The summed growing degree days for entire life cycle varied between 2628 (Kalojira) and 2759 (Radhunipagal), which could be supported by the fact that lengthening in growth duration (140.0 vs. 148.3 days) generally resulted in higher amount of accumulated heat. Similar findings on summed GDD for entire growth duration of scented rice cultivars were reported by Ghosh et al., (2005).

Table.1 Effect of cultivars on phenological development of indigenous aromatic rice during kharif season (pooled over two years)

\begin{tabular}{|c|c|c|c|c|c|c|c|c|c|}
\hline \multirow[b]{2}{*}{ Cultivar } & \multicolumn{4}{|c|}{ Vegetative } & Repro ductive & \multicolumn{3}{|c|}{ Ripening } & Life cycle \\
\hline & S-E & E-4LE & 4LE-AT & AT-PI & PI-F & F-Mi & Mi-D & D-M & S-M \\
\hline Gobindabhog & 3.5 & 7.5 & 25.0 & 26.5 & 37.8 & 10.5 & 10.5 & 10.2 & 141.5 \\
\hline Badshabhog & 3.8 & 18.2 & 26.0 & 25.0 & 37.5 & 11.5 & 11.5 & 11.0 & 144.5 \\
\hline Mohanbhog & 4.0 & 17.5 & 26.2 & 27.5 & 37.7 & 11.2 & 11.0 & 11.2 & 146.3 \\
\hline Radhunipagal & 4.5 & 17.0 & 25.8 & 30.7 & 37.2 & 11.0 & 11.2 & 11.0 & 148.4 \\
\hline Kalojira & 3.2 & 17.3 & 25.5 & 23.5 & 38.0 & 11.0 & 10.8 & 10.7 & 140.0 \\
\hline Chinikamini & 4.0 & 18.0 & 26.0 & 27.8 & 37.8 & 11.2 & 11.2 & 11.3 & 147.3 \\
\hline Khasdhan & 4.0 & 18.0 & 25.5 & 24.8 & 38.0 & 11.2 & 11.8 & 11.2 & 144.5 \\
\hline Mean & 3.9 & 17.6 & 25.7 & 26.5 & 37.7 & 11.1 & 11.1 & 10.9 & 144.6 \\
\hline S.Em.( $( \pm)$ & 0.42 & 0.42 & 0.40 & 2.39 & 0.13 & 0.13 & 0.15 & 0.14 & 0.34 \\
\hline CD at $5 \%$ & 1.24 & 1.24 & NS & 6.96 & 0.39 & 0.39 & 0.45 & 0.42 & 0.95 \\
\hline
\end{tabular}

$\mathrm{S}-\mathrm{E}=$ sowing to emergence, $\mathrm{E}-4 \mathrm{LE}=$ emergence to $4^{\text {th }}$ leaf emergence, $4 \mathrm{LE}-\mathrm{AT}=4^{\text {th }}$ leaf emergence to active tillering, AT-PI = active tillering to panicle initiation, $\mathrm{PI}-\mathrm{F}=$ panicle initiation to $50 \%$ flowering,

$\mathrm{F}-\mathrm{Mi}=50 \%$ flowering to milk, Mi-D = milk to dough and $\mathrm{D}-\mathrm{M}=$ dough to maturity and $\mathrm{S}-\mathrm{M}=$ sowing to maturity 
Table.2 Accumulated thermal indices at growth stages of indigenous aromatic rice (Pooled over two years)

\begin{tabular}{|c|c|c|c|c|}
\hline Cultivar & $\begin{array}{l}\text { Vegetative } \\
\text { stage }\end{array}$ & $\begin{array}{c}\text { Reproductive } \\
\text { stage }\end{array}$ & $\begin{array}{l}\text { Ripening } \\
\text { Stage }\end{array}$ & Life cycle \\
\hline \multicolumn{5}{|c|}{ Growing degree days (GDD) } \\
\hline Gobindabhog & 1424 & 734 & 509 & 2667 \\
\hline Badshabhog & 1436 & 724 & 554 & 2714 \\
\hline Mohanbhog & 1476 & 726 & 528 & 2730 \\
\hline Radhunipagal & 1530 & 718 & 511 & 2759 \\
\hline Kalojira & 1365 & 738 & 525 & 2628 \\
\hline Chinikamini & 1488 & 729 & 526 & 2743 \\
\hline Khasdhan & 1423 & 734 & 554 & 2711 \\
\hline Mean & 1449 & 729 & 530 & 2708 \\
\hline \multicolumn{5}{|c|}{ Heliothermal units (HTU) } \\
\hline Gobindabhog & 6327 & 4435 & 4278 & 15040 \\
\hline Badshabhog & 6502 & 4271 & 4627 & 15400 \\
\hline Mohanbhog & 6616 & 4565 & 4298 & 15479 \\
\hline Radhunipagal & 6842 & 4717 & 4119 & 15678 \\
\hline Kalojira & 5936 & 4275 & 4538 & 14749 \\
\hline Chni Kamini & 6658 & 4669 & 4241 & 15568 \\
\hline Khasdhan & 6427 & 4326 & 4624 & 15377 \\
\hline Mean & 6473 & 4465 & 4389 & 15327 \\
\hline \multicolumn{5}{|c|}{ Photothermal units (PTU) } \\
\hline Gobindabhog & 18134 & 8741 & 5800 & 32675 \\
\hline Badshabhog & 18282 & 8625 & 6310 & 33217 \\
\hline Mohanbhog & 18768 & 8644 & 5991 & 33403 \\
\hline Radhunipagal & 19421 & 8493 & 5826 & 33740 \\
\hline Kalojira & 17424 & 8827 & 6069 & 32320 \\
\hline Chinikamini & 18922 & 8673 & 5961 & 33556 \\
\hline Khasdhan & 18125 & 8750 & 6291 & 33166 \\
\hline Mean & 18439 & 8679 & 6035 & 33153 \\
\hline
\end{tabular}

Table.3 Correlations between GDD and HTU at different growth stages and yield associated parameters of indigenous aromatic rice

\begin{tabular}{|c|c|c|c|c|c|}
\hline $\begin{array}{c}\text { Thermal } \\
\text { indices at } \\
\text { phenophases }\end{array}$ & $\begin{array}{l}\text { Panicle } \\
\text { length }\end{array}$ & $\begin{array}{c}\text { No. of } \\
\text { panicles } \mathrm{m}^{-}\end{array}$ & $\begin{array}{l}\text { No. of filled } \\
\text { grains panicle }\end{array}$ & $\begin{array}{c}1000 \text { grain } \\
\text { weight }\end{array}$ & Grain yield \\
\hline \multicolumn{6}{|c|}{ Growing degree days (GDD) } \\
\hline AT - PI & -0.106 & $0.348^{*}$ & 0.159 & -0.186 & -0.270 \\
\hline $\mathbf{P I}-\mathbf{F}$ & 0.166 & -0.288 & 0.034 & 0.012 & 0.141 \\
\hline F - Mi & 0.069 & $-0.532 * *$ & 0.101 & -0.119 & -0.116 \\
\hline Mi - D & $-0.492 * *$ & -0.020 & $-0.599 * *$ & -0.141 & $-0.395 * *$ \\
\hline $\mathbf{D}-\mathbf{M}$ & -0.072 & $-0.330^{*}$ & 0.010 & -0.218 & $-0.309 *$ \\
\hline & & & & & \\
\hline \multicolumn{6}{|c|}{ Heliothermal units (HTU) } \\
\hline AT - PI & $-0.339 *$ & $0.453 * *$ & -0.303 & 0.115 & -0.020 \\
\hline PI - F & -0.099 & $0.581 * *$ & -0.118 & 0.229 & -0.089 \\
\hline $\mathbf{F}-\mathbf{M i}$ & 0.149 & -0.390 & 0.235 & -0.213 & -0.181 \\
\hline Mi - D & -0.245 & -0.024 & $-0.436 * *$ & 0.031 & 0.087 \\
\hline $\mathbf{D}-\mathbf{M}$ & $0.0474 * *$ & 0.071 & 0.138 & $0.386 *$ & $0.333 *$ \\
\hline
\end{tabular}

Sample size; $\mathrm{n}=42$

$\mathrm{r}$ value $=0.304^{*}$ and $0.393^{* *}$ at $5 \%$ and $1 \%$ level of significance, respectively 
Table.4 Multiple regression equations for prediction of yield associated characteristics and yield of aromatic rice

\begin{tabular}{|c|c|c|}
\hline Parameter & Equation & $\mathbf{R}^{2}$ \\
\hline Panicle length & $\mathrm{Y}=31.08-0.048 \mathrm{GDD}_{\mathrm{Mi}-\mathrm{D}} * *+0.0014 \mathrm{HTU}_{\mathrm{D}-\mathrm{M}} * *$ & $0.46 * *$ \\
\hline No. of panicles $\mathrm{m}^{-2}$ & $\mathrm{Y}=499.89+0.05 \mathrm{HTU}_{\mathrm{PI}-\mathrm{F}} * *-0.59 \mathrm{GDD}_{\mathrm{PI}-\mathrm{F}} *$ & $0.41 *$ \\
\hline No. of filled grains panicle ${ }^{-1}$ & $\mathrm{Y}=224.05-0.66 \mathrm{GDD}_{\mathrm{Mi}-\mathrm{D}} * *$ & $0.36 * *$ \\
\hline 1000 grain weight & $\mathrm{Y}=10.08+0.0004 \mathrm{HTU}_{\mathrm{D}-\mathrm{M}} *$ & $0.15 *$ \\
\hline Grain yield & $\mathrm{Y}=3.93-0.0138 \mathrm{GDD}_{\mathrm{Mi}-\mathrm{D}} * *-0.000724 \mathrm{HTU}_{\mathrm{Mi}-\mathrm{D}} *$ & $0.34 * *$ \\
\hline Straw yield & $Y=1.14+0.00087$ HTU $_{\text {PI-F }} * *$ & $0.41^{* * * *}$ \\
\hline
\end{tabular}

$\mathrm{GDD}_{\mathrm{PI}-\mathrm{F}}=\mathrm{GDD}$ (panicle initiationto $50 \%$ flowering); $\mathrm{GDD}_{\mathrm{Mi}-\mathrm{D}}=\mathrm{GDD}$ (milk to dough)

$\mathrm{HTU}_{\mathrm{PI}-\mathrm{F}}=\mathrm{HTU}$ (panicle initiation to $50 \%$ flowering); $\mathrm{HTU}_{\mathrm{Mi}-\mathrm{D}}=\mathrm{HTU}$ (milk to dough); $\mathrm{HTU}_{\mathrm{D}-\mathrm{M}}=\mathrm{HTU}$ (dough to maturity)

The summed GDD and PTU for all seven cultivars were slightly higher during 2009 than 2008 mainly due to longer vegetative phase accompanied with greater air temperature and photoperiod during the period; while summed HTU was greater in earlier year due to more sunshine hours during vegetative phase than the later year of study. Based on accumulated GDD, HTU and PTU for entire life cycle, the cultivars could be arranged as: Radhunipagal $>$ Chinikamini > Mohanbhog > Badshabhog > Khasdhan > Gobindabhog > Kalojira.

\section{Correlations and yield prediction models}

The correlation studies revealed that GDD influenced tiller production positively $(\mathrm{r}=$ $0.348^{*}$ ) during active tillering to panicle initiation stage, which ultimately led to greater number of panicles $\mathrm{m}^{-2}$ at maturity (Table 3). But HTU during both tiller production and panicle determination stages (i.e. active tillering to panicle initiation and panicle initiation to $50 \%$ flowering) had positive influence $(\mathrm{P}<0.01)$ on number of panicles $\mathrm{m}^{-2}$ Mean bright sunshine hours during milk to dough (9.56 vs. 8.58 hours) and dough to maturity (8.67 vs. 7.15 hours) were higher in 2008 than 2009, which resulted in better grain filling and development during earlier than later year of investigation. Accordingly, HTU during dough to maturity stage had positive influence $\left(\mathrm{r}=0.386^{*}\right)$ on 1000 grain weight. Grain yield was negatively correlated with GDD at milk to dough and dough to maturity stage, while positively correlated with HTU during dough to maturity stage in the study. The regression model for grain yield $(\mathrm{Y}=3.93-$ 0.0138 GDDM-D** -0.000724 HTUM-D*) showed associations with GDD and HTU both during milk to dough stage and accounted for $34 \%$ variation at $1 \%$ level of significance (Table 4). Mandal and Ghosh (2003) reported similar yield prediction models for hybrid rice in West Bengal.

Aromatic rice landraces of West Bengal were long-duration types (>140 days) and they required mean GDD, HTU and PTU of 2708, 15327 and 33153 for entire life cycle, respectively.

GDD and HTU at tiller production stage had positive influence on number of panicle $\mathrm{m}^{-2}$, while HTU at ripening stage showed positive impact on grain filling and development leading to higher grain yield.

\section{Acknowledgement}

The authors are thankful to Sri Kitab Ali Mandal, Sri Nirmal Biswas and Sri Sunil Bhnuia for their cooperation during the field work of the study. 


\section{References}

Bhattacharya, B., 2003. West Bengal Government lays stress on exporting premium rice strains. The Indian Express, Financial Express section, Net Edition. July 7, 2003.

Ghosh, M., Mondal, B.K., Mondal, B.B., Lodh, S.B., and Dash, A.B., 2005. Performance of aromatic rice cultivars in new alluvial zone of West Bengal. Oryza, 42 (3): 184-187.

Mandal, Nakul, and Ghosh, Mrityunjay, 2003. Thermal time indices and correlations for hybrid rice in Terai zone of West Bengal. Journal of Agrometeorology, 5 (2): 98-101.

Oldeman, L.R., Seshu, D.V., and Caddy, F.B., 1987. Response of rice to weather variables. In: Weather and Rice (Eds. Seshu, D.V., La Ru Pollard, $M$ and Cervantes, E. P.). IRRI, Manila, Philippines, pp.5-39.

Sreenivas, G., Reddy, M.D., and Reddy, D.R., 2010. Agrometeorological indices in relation to phenology of aerobic rice. Journal of Agrometeorology, 12 (2): 241-244.

\section{How to cite this article:}

Sibajee Banerjee, Mrityunjay Ghosh and Debasis Mazumder. 2018. Phenology, Thermal Indices and Yield Prediction Models of Indigenous Aromatic Rice of West Bengal, India. Int.J.Curr.Microbiol.App.Sci. 7(03): 1645-1650. doi: https://doi.org/10.20546/ijcmas.2018.703.197 